\title{
Czarnobylska modlitwa. Kronika przyszłości Swietłany Aleksijewicz: konflikt postkatastroficznych narracji
}

\section{Chernobyl Prayer: A Chronicle of the Future Conflict in Postcatastrophic Narrations}

\begin{abstract}
Svetlana Alexievich's Chernobyl Prayer: A Chronicle of the Future is a collection of narratives created after the catastrophe at the Chernobyl nuclear power plant. The paper presents the posttraumatic reality as an inexpressible experience that cannot be explained or described. However, the inability to represent traumatic experience does not mean falling into silence. Instead, it rouses the imagination. Interviews with victims of the catastrophe carried out by the author confirm the existence of a specific, collective "imaginarium" of the conceptual realm, where the process of fantasizing actuates discourse, both metaphysical-apocalyptic and other, and also evokes the aestheticization of the disaster, as well as irony. The emergence of different languages reflects the possible ways of perceiving posttraumatic reality and creating postcatastrophic discourse. The catastrophe, which creates a threat - and simultaneously, an attraction, an unreal object of desire - is terrifying and at the same time ridiculous.
\end{abstract}

Key words: Alexievich Svetlana, Chernobyl Prayer: A Chronicle of the Future, Chernobyl, disaster, trauma

Streszczenie: Czarnobylska modlitwa. Kronika przyszłości Swietłany Aleksijewicz jest zbiorem narracji powstałych po wybuchu elektrowni jądrowej w Czarnobylu. Publikacja przedstawia posttraumatyczną rzeczywistość jako przestrzeń „niewyrażalną”, niedającą się wytłumaczyć lub opisać. Brak możliwości reprezentacji doświadczenia traumatycznego nie oznacza jednak 
popadnięcia w milczenie, lecz powoduje uruchamianie wyobraźni. Wywiady z ofiarami katastrofy przeprowadzone przez autorkę potwierdzają istnienie swoistego imaginarium zbiorowego, w którym snucie fantazji uruchamia m.in. metafizyczny dyskurs apokaliptyczny, a także powoduje estetyzacje katastrofy lub ironizowanie jej. Powstanie tak różnych języków odzwierciedla możliwe sposoby odbierania posttraumatycznej rzeczywistości, tworzenie dyskursu postkatastroficznego. Katastrofa, tworząc zagrożenie, jednocześnie przyciąga, stanowi odrealniony obiekt pożądania, jest przerażająca i zarazem śmieszna.

Słowa kluczowe: Aleksijewicz Swietłana, Czarnobylska modlitwa. Kronika przyszłości, Czarnobyl, katastrofa, trauma

Katastrofa jako wydarzenie nagłe i nieprzewidywalne stanowi moment przełomowy. Zaburzając ciągłość historii, budzi lęk, destabilizuje podmiot i wywołuje poznawczy niepokój. Mimo wielu jej opisów w tekstach kultury ${ }^{1}$, każda jest zjawiskiem wyjątkowym. Na jej szczególny charakter składa się nie tylko każdorazowo inny przebieg akcji, lecz również jej traumatyczny charakter. Wydarza się jeden raz, ale później ciągle powraca w postkatastroficznych narracjach. Perspektywa post- wskazuje na czas tworzenia dyskursu katastrofy (przekazów medialnych, opowieści świadków, dzieł sztuki i innych licznych interpretacji), a także przekierowuje uwage z wydarzenia na sytuację po nim, na „zmagania z katastrofą po katastrofie" ${ }^{\prime 2}$.

Czarnobylska modlitwa. Kronika przyszłości Swietłany Aleksijewicz jest zbiorem świadectw powstałych po wybuchu elektrowni jądrowej w Czarnobylu 26 kwietnia 1986 roku. Publikacja ta zawiera historie uczestników akcji ratowniczej, mieszkańców skażonych terenów, a także każdego, kogo katastrofa dotknęła; stanowi zarówno upamiętnienie wydarzenia, jak i jest próbą jego wytłumaczenia.

Awaria w czarnobylskiej elektrowni jądrowej jako największa katastrofa technologiczna XX wieku podzieliła historię na "przed” i „po”. „Patrzę na Czarnobyl jak na początek nowej historii - jest on nie tylko wiedzą, ale i przed-wiedzą, dlatego że człowiek wstąpił

1 Zob. S. Sontag: Katastrofa w wyobrażeniu. Tłum. A. Sкucińska. W: S. Sontag: Przeciw interpretacji i inne eseje. Kraków 2018, s. 279-301.

2 Zob. A. Artwińska, P. Czapliński, A. Molisak, A. Tippner: Po Zagładzie. Narracje postkatastroficzne w literaturze polskiej. „Poznańskie Studia Polonistyczne. Seria Literacka" 2015, nr 25, s. 16. 
w spór z poprzednimi wyobrażeniami o sobie i świecie"3 - pisze Aleksijewicz. Rozumienie katastrofy jako sytuacji granicznej, momentu zwrotnego, zmiany sygnalizuje powstanie rzeczywistości niezgodnej z dotychczasową. Spróbuję skupić się na najważniejszych cechach świata po Czarnobylu, na skutkach i oddziaływaniu katastrofy, sposobie jej funkcjonowania w pamięci świadków, które zostały zaakcentowane przez rozmówców Aleksijewicz oraz samą autorkę.

Dzisiaj znamy czas wybuchu reaktora co do sekundy. Katastrofa jednak nie jest wydarzeniem krótkotrwałym, lecz rozciągniętym w czasie. Stanowi zwrot ku przeszłości (dlaczego to się stało?), każe stawiać pytania o teraźniejszość (czym jest katastrofa i jakie są jej skutki?) i przyszłość (co będzie potem?). Doświadczenie katastrofy, jak każde doświadczenie traumatyczne, nie jest punktowe: choć odnosi się do konkretnego wydarzenia, które pozwala się datować, nie pozostaje zamknięte, ograniczone historią ${ }^{4}$. W przypadku Czarnobyla zaburzenie czasowości ma jeszcze bardziej skomplikowany charakter. Aleksijewicz pisze: „Między czasem, w którym doszło do katastrofy, a czasem, kiedy zaczęto o niej opowiadać, powstała luka. Chwila oniemienia” (Cm, s. 33). W pewnym sensie to "katastrofa wsteczna"5: starannie ukrywana przez władze nie od razu zaistniała w dyskursie medialnym; wydarzenie trudne i wymykające się opisowi, a więc z opóźnieniem zaczyna produkować narracje na swój temat, wyróżniające się niezwykłą różnorodnością i sprzecznością. Książka Aleksijewicz, pisana i poszerzana w kolejnych wydaniach przez kilkanaście lat (1986-2005), wypełnia ciszę, ponownie odtwarzając katastrofę poprzez świadectwa. Relacje świadków, pogłoski i mity przez długi czas stanowiły główne źródło wiedzy na temat wypadku w czarnobylskiej elektrowni jądrowej: dopiero po dwudziestu, trzydziestu latach zostaje zniesiona cenzura i w archiwach udostępniane są dokumenty dotyczące awarii ${ }^{6}$.

3 S. Aleksijewicz: Czarnobylska modlitwa. Kronika przyszłości. Tłum. J. Сzech. Wołowiec 2018, s. 30. Dalej, cytując fragmenty książki, posługuję się skrótem $\mathrm{Cm}$, po nim podaję numer strony.

4 Zob. D. LaCapra: Historia w okresie przejściowym: doświadczenie, tożsamość, teoria krytyczna. Tłum. K. Bojarska. Kraków 2009, s. 76; Zob. C. Caruth: Introductio. In: Trauma. Explorations in memory. Ed. C. CARUth. Baltimore 1995, s. 8.

${ }^{5}$ Zob. P. Czapliński: Katastrofa wsteczna. „Poznańskie Studia Polonistyczne. Seria Literacka" 2015, nr 25.

${ }^{6}$ Zob. K. Brown: Czarnobyl. Instrukcje przetrwania. Tłum. T.S. GaŁązKa. Wołowiec 2019, s. 12-13. 
Czarnobyl to „katastrofa bez wyraźnego końca”, konsekwencje wybuchu - wydaje się - będą trwać wiecznie. Naukowcy nie potrafią dokładnie oszacować jej skutków dla środowiska, wpływu promieniowania na zdrowie. Nie można sprowadzić awarii do konkretnej czasoprzestrzeni - radioaktywne chmury rozniosły się po całej Europie, natomiast ciągłe rozbudowanie dyskursu postkatastroficznego o nowe interpretacje i konteksty odsłania wielowarstwowość kategorii czasu ${ }^{8}$. Wybuch w Czarnobylu zapoczątkował historie katastrof: alarmując o wcześniejszych ukrytych wypadkach jądrowych ${ }^{9}$ oraz obnażając potencjalne zagrożenia, wyznaczył kierunek myślenia o przyszłości, co bardzo dobrze oddaje tytuł omawianej publikacji. Katastrofa odżywa nieustannie - w intencji przezwyciężenia traumy jest odgrywana ${ }^{10}$ jako próba opisu, wytłumaczenia oraz jako ostrzeżenie przed powtórzeniem. Czarnobyl nawiedza bohaterów reportażu Aleksijewicz, dla których, zdaniem autorki, staje się „zasadniczą treścią ich świata” (Cm, s. 34), a jego powrót w narracjach znacząco skraca dystans między przeszłością a momentem opowieści. Wraz z wzajemnym przenikaniem się czasów paradoksalnie następuje ich podział, a nawet rozpad. Czarnobyl niszczy przeszłość, a razem z nią narzędzia poznania rzeczywistości, którymi człowiek dysponował. Jest wyjątkową katastrofą, dziejąc się po raz pierwszy, otwiera początek dla następujących po niej zbieżnych wydarzeń, a jednocześnie zapowiada koniec starego świata.

Dopełniając listy historycznych katastrof, Czarnobyl „dzięki Aleksijewicz stał się miejscem tego, co traumatyczne, »niewyrażalne« w kulturze ${ }^{\prime 11}$. Wybór świadectwa jako sposobu opowiedzenia

${ }^{7}$ Ibidem, s. 18.

${ }^{8}$ O nakładaniu się na siebie struktur czasowych w dyskursie postkatastroficznym zob. A. Artwińska: „Odrodzity się traumy z czasów Zagłady”. Marzec 1968 jako narracja postkatastroficzna. „Poznańskie Studia Polonistyczne. Seria Literacka" 2015, nr 25, s. 187-208.

9 O nieznanych katastrofach nuklearnych zob. K. Brown: Plutopia. Tłum. T. Bieroń. Wołowiec 2019.

${ }^{10} \mathrm{O}$ różnicy między odgrywaniem (actin out) jako „kompulsywnym i dyskursywnym odtwarzaniu zdarzen'" a przepracowaniem (working through) pisał D. LaCApra. Zob. Idem: Historia w okresie przejściowym..., s. 178; Idem: Trauma, nieobecność, utrata. W: Antologia studiów nad trauma. Red. T. ŁysaK. Przekł. T. BILczewski, K. Bojarska, J. Burzyński, A. Kowalcze-Pawlik, A. Rejniak-Majewska. Kraków 2015, s. 85.

${ }^{11}$ Zob. T. Hundorowa: Gatunek Czarnobylski: wyparcie realnego i nuklearna sublimacja. Tłum. P. Tомаneк. W: Po Czarnobylu. Miejsce katastrofy w dyskursie 
o katastrofie tylko na pozór pozwala na obiektywne przedstawienie pełnego obrazu tragedii. Autorkę natomiast nie interesuje przebieg wydarzenia (nie pyta, co mogło doprowadzić do wybuchu reaktora, kto popełnił błąd), ale jego wpływ na losy poszczególnych osób, ich reakcja na katastrofę, która nadal oddziałuje na rzeczywistość po przewrocie. Reportaż Aleksijewicz, pokazujący część "czarnobylskiej historii mówionej"12, przedstawia świat po katastrofie jako przestrzeń, niedającą się wytłumaczyć lub opisać. Jest to „skok w nową rzeczywistość, której nie była w stanie ogarnąć nie tylko nasza wiedza, ale nawet wyobraźnia" (Cm, s. 33). Gwałtowne zmiany, przyniesione przez Czarnobyl, są trudne do zrozumienia i zaakceptowania przede wszystkim dlatego, że wykraczają poza pole percepcyjne. Aleksijewicz pisze w prologu:

Człowieka zaskoczono nagle, nie był na to wszystko przygotowany. Nie był gotów jako gatunek biologiczny, nie zadziałał cały jego naturalny aparat, nastawiony na to, żeby zobaczyć, posłuchać, dotknąć. Jego oczy, uszy, palce już się nie nadawały, nie mogły mu służyć, bo promieniowania nie widać, bo nie ma zapachu ani nie wydaje dźwięku. Jest bezcielesne.

Cm, s. 35

Świat po katastrofie, znajomy i obcy jednocześnie, rozpada się na oczach bohaterów Czarnobylskiej modlitwy... Świadomość nieodwracalności tragedii przeplata się w narracjach z poczuciem bezradności wobec tego, co niedostrzegalne, niewidoczne. Podważanie zagrożenia, którego nie sposób zobaczyć, służy zniwelowaniu różnic, zredukowaniu przepaści między starym a nowym światem. Ten ostatni, rządzący się innymi regułami, wydaje się absurdalny, nielogiczny podstawowe czynności takie, jak picie wody ze źródła, kąpanie się w rzece, siedzenie na trawie stają się niebezpieczne. Miejsca i przedmioty są obce, teraz to tylko ślady po czymś, co było kiedyś znane: „Bierzemy kiełbasę, jajka... Robimy zdjęcie rentgenowskie - znowu radioaktywne odpady" (Cm, s. 195). Resztki świata po Czarnobylu porzucone miasta i wsie, zabite studnie i mogiły, w których starano się pochować skażone domy, zwierzęta, ziemię - świadczą o braku możliwości powrotu do pełni, do rzeczywistości sprzed katastrofy: "Czarnobyl... Nie będziemy już mieli innego świata..." (Cm, s. 174). Chaotyczność, fragmentaryczność wypowiedzi zebranych w książce,

wspótczesnej humanistyki. Red. I. Boruszkowska, K. Glinianowicz, A. Grzemska, P. KRupa. Kraków 2017, s. 56.

12 Ibidem, s. 55. 
pauzy i niedomówienia oddają szczątkowość świata po kataklizmie, załamany porządek rzeczy ${ }^{13}$.

Katastrofa czarnobylska, pozbawiona formy, naznaczona negatywnością, usiłuje zaistnieć $\mathrm{w}$ mowie, ale próby te eksponują ograniczoność języka lub jego utratę, niszczą kategorie pojęciowe, odsłaniając pustkę znaczonego. Takie zakłócenie komunikacji, kiedy zjawisko nie przeobraża się $\mathrm{w}$ znak, podkreśla destrukcyjne działanie wydarzenia. Tamara Hundorowa, powołując się na Derridiańskie pojęcie różni (différance) $)^{14}$, opisuje sposób „przyswojenia rzeczywistości postczarnobylskiej", graniczny charakter katastrofy oraz jej paraliżującą moc $^{15}$. Mnogość głosów i poglądów na temat wypadku, zdaniem ukraińskiej badaczki, zawiesza świadomość podmiotu. Poczucie, że wydarzenie nie może realizować się w języku, nie redukuje jednak przywoływania katastrofy: podmiot budzi się z koszmaru, żeby zacząć świadczyćc ${ }^{16}$. „Czarnobyl zrodził swojego świadka"17, który usiłuje zmierzyć się z pustką po awarii, aby następnie ją wypełnić. Wiedza, doświadczenie i zmysły zawodzą bohaterów Czarnobylskiej modlitwy..., ale to nie powstrzymuje ich przed wypowiadaniem się: „Chcę zaświadczyć, że moja córka umarła na Czarnobyl. [...] Mówią, że to naukowo jeszcze niedowiedzione, że nie ma bazy danych. [...] Niech chociaż pani to napisze..." (Cm, s. 53). Aleksijewicz nie dąży do nadania wypowiedziom jedności, pisze "tekst katastrofy", nie próbując zdobyć władzy nad nią, nie tworząc zamkniętych pojęć i kategorii.

Katastrofa uruchamia archiwum i prowadzi do historycznych porównań, przede wszystkim z wojną jako zjawiskiem zajmującym centralne miejsce w pamięci zbiorowej mieszkańców Białorusi i Ukrainy. Jedna z bohaterek rozważa: „To zachowanie wydawało mi się czymś znajomym, chociaż urodziłam się po wojnie. Starałam się analizować swoje uczucia i byłam zdumiona, jak szybko moja psychika się przestawiła, jak niepostrzeżenie zdobyłam doświad-

${ }^{13}$ I. Boruszkowska pisze o nowym stylu czarnobylskim - z graficznie zaznaczonymi pauzami i niepełnymi zdaniami - w tekstach, bazujących na opowieściach świadków. Zob. I. BoruszKowsкA: Mapowanie apokalipsy - pustka i ślad czarnobylskiej zony w narracjach postczarnobylskich. W: Po Czarnobylu..., s. 84.

${ }^{14}$ J. Derrida: Różnia. W: Idem: Marginesy filozofii. Tłum. A. Dziadek, J. MarGaŃSKi, P. PieniążeK. Warszawa 2002, s. 29-56.

${ }^{15}$ Zob. T. Hundorowa: Czarnobyl, nuklearna apokalipsa i postmodernizm. Tłum. I. BoruszKowska. „Teksty Drugie” 2014, nr 6, s. 255.

${ }^{16}$ Zob. C. CAruth: Traumatyczne przebudzenia (Freud, Lacan i etyka pamięci). Tłum. K. Bojarska. W: Antologia studiów nad trauma..., s. 31-57.

17 Zob. T. Hundorowa: Gatunek Czarnobylski..., s. 60. 
czenie wojny" (Cm, s. 176). Być może dzięki narracjom rodzinnym, "odziedziczonym" obrazom i historiom ${ }^{18}$ wojna wydaje się kobiecie doświadczeniem bliższym oraz łatwiejszym do zrozumienia. Władze państwa, ustanawiając ramy poznawcze sytuacji po wypadku w czarnobylskiej elektrowni jądrowej, również chętnie sięgają po analogie z wojną, co ma posłużyć lepszemu oswajaniu społeczeństwa z tragedią: „Do wsi... Do fabryk... Przyjeżdżali pracownicy komitetów rejonowych partii... [...] Wygłaszali odczyty o heroizmie ludzi radzieckich, o symbolach wojennego męstwa, knowaniach zachodnich wywiadów..." (Cm, s. 180). Wybór takiej strategii politycznej - podkreślanie sprawczości człowieka oraz wielkiego imperium - służył zapobieganiu niepożądanej paniki oraz budował poczucie wspólnoty, zjednoczenia się $\mathrm{w}$ walce $\mathrm{z}$ przeciwnikiem. Porównania $\mathrm{z}$ wojną lub innymi znanymi tragicznymi zjawiskami nie przynoszą jednak uspokojenia, katastrofa czarnobylska wymyka się próbom wytłumaczenia.

We wstępie do książki Społeczeństwo ryzyka. W drodze do innej nowoczesności, opublikowanej zaraz po wydarzeniach w Czarnobylu, Ulrich Beck głosi koniec „wszystkich, tak pieczołowicie przez nas hodowanych możliwości dystansowania się"19. Przemoc, która dotychczas wiązała się z kategorią ,innych", nabiera nowego znaczenia: realne i symboliczne granice znikają, uniemożliwiając odizolowanie się od „niebezpieczeństw epoki atomu"20. W Czarnobylskiej modlitwie... pojawia się obraz katastrofy jako doświadczenia totalnego - wypełniającego człowieka i cały świat radiacją, wszechogarniającą śmiercią. W Monologu pewnej wsi czytamy: „Czarnobyl... To wojna nad wojnami. Człowiek nigdzie się nie ukryje. Ani na ziemi, ani w wodzie, ani na niebie" (Cm, s. 60). Zagrożenie, jakie niesie skażenie promieniotwórcze, dotyczy i dotyka wszystkich, zawiesza albo unieważnia opozycję ofiara - sprawca, stając się wydarzeniem niczyim, „bezpańskim”21. Katastrofa zmienia obraz wroga, „wciela się" w naturę i człowieka: „Zabijały nas skoszona trawa, złowiona ryba, upolowana zwierzyna.

${ }^{18}$ Odwołuję się tu do kategorii postpamięci autorstwa Marianne Hirsch. Zob. Eadem: Family Frames. Photography, Narrative, and Postmemory. Cambridge 1997.

19 Zob. U. Bеск: Społeczeństwo ryzyka. W drodze do innej nowoczesności. Tłum. S. Cieśla. Warszawa 2006, s. 11.

${ }^{20}$ Ibidem.

${ }^{21}$ C. Caruth, używając pojęcia unclaimed experience, pokazuje, że doświadczenie traumatyczne nigdy nie należy wyłącznie do ofiar historycznych. Zob. Eadem: Doświadczenie niczyje: trauma i możliwość historii. Freud, Mojżesz i monoteizm. Tłum. K. BojarsKa. „Teksty Drugie” 2010, nr 6, s. 122. 
Jabłko..." (Cm, s. 35). Zmaganie się z radiacją - opuszczanie domów, rozstrzeliwanie zwierząt domowych, zakopywanie drzew i ziemi wydaje się rozmówcom Aleksijewicz irracjonalne, a więc jeszcze bardziej paraliżuje możliwości poznawcze.

Świadkowie próbują wpisać czarnobylską awarię w dyskurs myślenia o konfliktach zbrojnych, poszukują schematu postępowania, potwierdzenia swoich przemyśleń. Szukając odpowiedzi w pamięci, sięgają również po teksty kultury („Nie czytałam takich książek... Nie widziałam filmów”; Cm, s. 114), opinie autorytetu („Cały czas czekam, aż ktoś mądry mi to wytłumaczy... Rozłoży..."; Cm, s. 166) oraz zwracają się do rządu jako źródła wiedzy („Ludzie nie wierzą gazetom, telewizji i radiu, szukają wskazówek w zachowaniu władz. To jest najpewniejsze źródło"; Cm, s. 136). Próba opisu doświadczenia katastrofy stanowi przykład realizacji władzy dyskursu (normatywnej i symbolicznej) w relacji między zjawiskiem i poznającym go podmiotem. Czarnobyl przede wszystkim pełni funkcję emancypacyjną, „wyzwala” świadectwa: szokuje i odbiera mowę, ale zarazem skłania do wypowiedzi. „Tam zrozumiałem, że jestem bezradny. Że nie rozumiem. [...] Ale porozmawiałem z Panią i coś tymi słowami powiedziałem..." (Cm, s. 45) - wyznaje bohater Czarnobylskiej modlitwy...

W eseju Nie, apokalipso, nie teraz...22 Derrida przedstawia strategie zatrzymywania katastrofy, zapobiegania nieodwracalnej i całkowitej destrukcji, która polegałaby na wytworzeniu archiwum. W przypadku Czarnobyla, uruchamiającego symbolikę kresu, staje się metaforą zagłady całego świata ${ }^{23}$, archiwizacja oznacza nie tylko upamiętnienie, utekstowienie autentycznego wydarzenia, lecz również powstrzymanie prędkości zbliżania się ku końcowi. Niemożliwość reprezentacji doświadczenia traumatycznego domaga się wymyślenia nowego kodu, wysyła impuls do wyobraźni, która ma służyć powstaniu nowej formuły życia. Narracje wspomnieniowe, stanowiąc wytwór katastrofy, próbują zatem zapobiec ostatecznemu zniszczeniu świata.

Wywiady ze świadkami tragedii przeprowadzone przez Aleksijewicz potwierdzają istnienie swoistego imaginarium zbiorowego, gdzie snucie fantazji buduje m.in. dyskurs apokaliptyczny, a także powoduje estetyzację katastrofy lub ironizowanie jej. Przyczyn war-

${ }^{22}$ Zob. J. Derrida: Nie, apokalipso, nie teraz! (cała naprzód, siedem pocisków, siedem orędzi). W: Inem: O Apokalipsie. Tłum. I. Boruszkowszka, K. Wојтаsiк. Kraków 2018, s. 103-147.

${ }^{23}$ Zob. T. Hundorowa: Czarnobyl, nuklearna apokalipsa..., s. 257. 
tościowania Czarnobyla należy doszukiwać się nie tyle w zjawisku, ile w relacjach epistemologicznych, które zachodzą między odbiorcą a obiektem poznania ${ }^{24}$. Hundorowa, nawiązując do Jean-François Lyotarda ${ }^{25}$, zauważa: „Szczególny sens czarnobylskiego świadectwa polega na tym, że eksplozja jądrowa jest czymś absolutnie »niewyobrażalnym « i w tym sensie absolutnie wzniosłym" ${ }^{\prime 26}$. Katastrofa, tworząc zagrożenie, jednocześnie przyciąga, stanowi obiekt pożądania, co potwierdzają wypowiedzi likwidatorów awarii: „Kiedy mieliśmy wyjeżdżać, poczuliśmy strach. Ale na krótko. Bo już tam, potem - strach zniknął. [...] Korciło mnie, żeby popatrzeć na reaktor z góry, ze śmigłowca: co tam się naprawdę wydarzyło, jak to wygląda?" (Cm, s. 83). Wyjazd do Czarnobyla staje się dla wielu najważniejszym wydarzeniem $\mathrm{w}$ ich życiu, nie tylko ze względu na bezpośredni udział w likwidacji skutków tragedii, lecz również z punktu widzenia przeżytych tam emocji: „Oglądam się wstecz, na tamte dni... Byłem tuż obok czegoś... czegoś fantastycznego. Ale te słowa - "gigantyczne«, »fantastyczne« - nie oddają wszystkiego. Było takie uczucie... Jakie? (Zastanawia się). Takiego uczucia nie znałem nawet $\mathrm{w}$ miłości..." (Cm, s. 222). Pragnienie zobaczenia wybuchu, zbliżenia się do reaktora, spowodowane nieuchwytnością poznawczą katastrofy, przekształca Czarnobyl w widowisko, na co zwraca uwagę jeden z mieszkańców Prypeci (Cm, s. 52). Estetyzacja katastrofy jako spojrzenie zniekształcone, „z ukosa"27, pomaga ją zrozumieć, ujarzmić, a także przekierowuje uwagę ze zdarzenia na jego świadka. Poprzez kontakt ze zjawiskiem szczególnym czuje się on wyróżniony.

Unikatowe doświadczenie związane z Czarnobylem dotyczy również mieszkańców skażonych terenów, którzy, wracając do rodzimych domów po ewakuacji i wiedząc o niebezpieczeństwie, zaprzeczają katastrofie: „A po co wyjeżdżać? Tu jest dobrze! Wszystko rośnie, wszystko kwitnie. Od meszki do dzikiego zwierza, wszystko żyje [...]. No i jakie tu, mówię, promieniowanie, kiedy i motyl fruwa, i trzmiel brzęczy" (Cm, s. 48, 51). Uczucie bliskości człowieka $\mathrm{z}$ natura, pojednanie się z nią nadaje temu miejscu cechy

${ }^{24}$ Zob. A. Berleant: Prze-myśleć estetykę. Niepokorne eseje o estetyce i sztuce. Tłum. M. Korusiewicz, T. Markiewka. Kraków 2007, s. 173.

${ }_{25}$ Zob. J.-F. Lyotard: Odpowiedź na pytanie: co to jest postmodernizm? Tłum. M.P. Marкowsкi. W: Postmodernizm. Antologia przekładów. Wybrał, oprac. i przedmową, opatrzył R. Nycz. Kraków 1998, s. 55-56.

26 T. Hundorowa: Gatunek Czarnobylski..., s. 58.

27 Zob. S. Žıžeк: Patrząc z ukosa. Wprowadzenie do Jacques'a Lacana przez kulturę popularna. Tłum. J. Margański. Warszawa 2005, s. 26. 
arkadii: „Tu jest swoboda. Powiedziałbym nawet, że raj. Nie ma ludzi, same zwierzęta biegają. Żyję wśród ptaków i zwierząt" (Cm, s. 76). Czarnobylska sfera jako miejsce niedostępne dla wszystkich (przymusowe wysiedlenie mieszkańców terenów skażonych, następne ich ogrodzenie i zamknięcie) dla wielu staje się schronieniem, „przekształca się w pastoralną idyllę postapokaliptycznego świata"28. Jest to ziemia niczyja, odizolowana oraz rządząca się własnymi prawami: „Nie zginiemy bez Państwa! [...] Ziemi do woli, trawy do woli. Woda w studni jest. Wolność. Dobrze nam tu! Nie kołchoz mamy, ale komunę. Komunizm!" (Cm, s. 60).

Eksplozja elektrowni jądrowej przyśpieszyła rozpad ZSRR, zapoczątkowała narodziny nowej epoki i nowego myślenia ${ }^{29}$ : "[...] to nie reaktor eksplodował, ale cały dawny system wartości" (Cm, s. 202). Katastrofa odebrała wiarę $w$ dotychczasowe ideały: rozwój technologii, budowę społeczeństwa socjalistycznego - to, co miało służyć człowiekowi, obróciło się przeciwko niemu. Dla niektórych rozmówców Aleksijewicz Czarnobyl staje się utraconym sensem i wypełnia ich życie, zastępując poglądy ideologiczne, którymi żywili się od lat. Żona jednego z likwidatorów, rozpaczając nad jego śmiercią, zauważa:

Czarnobyl rozwalił imperium, wyleczył nas z komunizmu [...]. Ale ja nie mam nic więcej, nic innego, wyrosłam wśród takich słów i takich ludzi. [...] Czego się uchwycić? [...] Czarnobyl wypełnił moje życie i moja dusza się rozszerzyła.

Cm, s. 202

Podmiot po katastrofie znajduje się $\mathrm{w}$ punkcie bez możliwości powrotu, zostaje również pozbawiony przyszłości - czas zatrzymuje się dla niego. Katastrofa, niszcząc rzeczywistość jednostki, jednocześnie nadaje jej nowe znaczenie: „Boję się to powiedzieć, ale... kochamy Czarnobyl. Pokochaliśmy go, bo na nowo nadaje sens naszemu życiu... [...]" (Cm, s. 257). Świat po katastrofie czarnobylskiej, budowany na ruinach Związku Radzieckiego, okazuje się światem pustki, śladem idei i tęsknotą za przyszłością. A zarazem jest upragnionym miejscem, w którym może zamieszkać utopia.

Perspektywa post- $\mathrm{w}$ badaniach nad Czarnobylem eksponuje bezradność podmiotu: katastrofa, groźna i zarazem przyciągająca, za-

28 T. Hundorowa: Gatunek Czarnobylski..., s. 63.

29 Zob. EAdEM: Czarnobyl, nuklearna apokalipsa..., s. 252; J. Andruchowycz: Czarnobyl, mafia i ja. Tłum. L. Stefanowska. W: J. Andruchowycz: Ostatnie terytorium. Wołowiec 2002; O. Zaвużкo: Planeta Piołun - Dowżenko - Tarkowski - von Trier albo dyskurs nowej grozy. Tłum. K. KотүŃska. W: Po Czarnobylu... 
wsze jawi się jako niedostępna. Eksplozja i zniekształcenie systemu reprezentacji prowadzą do poznawczej bezradności. Kiedy język kapituluje, zaczyna przemawiać ciało, które jest tak samo rozbite, zdezintegrowane i niespójne jak rzeczywistość po katastrofie. Czarnobyl jako wydarzenie traumatyczne oddziałuje z opóźnieniem: powraca nie tylko we wspomnieniach, ale także ujawnia się poprzez ciało, które czuje się coraz bardziej chore. Tym sposobem katastrofa staje się coraz bardziej obecna.

O kategorii podmiotu somatycznego pisze Aleksandra Ubertowska:

Ciało staje się bytem autonomicznym, wyłamuje się z ram konstrukcji spekulatywnych, klasyfikujących, a staje się istotnym medium, za pomocą którego człowiek rozpoznaje świat, ustanawiając swoje w nim miejsce ${ }^{30}$.

Mimo słabości i nietrwałości ciało wydaje się najbardziej wiarygodnym świadkiem wydarzenia granicznego, gdyż stawia opór wobec dyskursu publicznego ${ }^{31}$. Język poszukuje środków wyrazu poza sobą, w bólu i cierpieniu przekazywanym przez ciało naznaczone śladem katastrofy. Jeden z likwidatorów mówi: „Wróciłem... I wszystko się dopiero zaczyna [...]. Minęło dziesięć lat, gdybym nie zachorował, tobym zapomniał..." (Cm, s. 86). Ciało zanurzone w dziejowości, poddane presji wydarzenia staje się archiwum, dokumentem, źródłem historycznym - pamięć korporalna zapisuje wypadek jądrowy na materialnym nośniku:

Wasia zaczął się zmieniać - codzienne przychodziłam do kogoś innego... Oparzenia wychodziły na wierzch... W ustach, na języku, na policzkach - najpierw pojawiały się małe ranki, potem się rozrastały. Śluzówka odchodziła płatami, takie białe błonki... Kolor twarzy... Kolor ciała... Siny... Czerwony... Szarobrunatny... A ono jest takie całe moje, takie kochane! Tego nie da się wypowiedzieć.

Cm, s. 18-19

Ucieleśniona pamięć o Czarnobylu odsłania mechanizmy „biopolityki" ${ }^{\prime 2}$ jako demonstracji władzy państwa polegającej na ",trosce”

30 A. Ubertowska: Holokaust. Auto(tanato)grafie. Warszawa 2014, s. 55.

31 Zob. ibidem, s. 255.

${ }^{32}$ M. Foucault: Historia seksualności. Przeł. B. Banasiak, T. Komendant, K. Matuszewski. Warszawa 1995, s. 125. 
o życie obywateli: możliwe skutki choroby popromiennej są ukrywane przed pacjentami, kobietom zaleca się wykonywanie aborcji, a likwidatorzy zostają zamknięci w szpitalach z zakazem odwiedzania ich przez rodziny. Aleksijewicz zaznacza: „Zamiast tradycyjnie pocieszać żonę umierającego męża, lekarz mówi jej teraz: »Nie wolno do niego podchodzić! Nie wolno go całować! Nie wolno głaskać!«" (Cm, s. 40).

Ciało, boląc i rozpadając się, zaczyna świadczyć w imieniu podmiotu, umieszcza katastrofę w strefie doświadczeń fizycznych, co złudnie pomaga wyrazić „niewyrażalne”. Jednocześnie odsłania kruchość i ograniczoność zdominowanego przez chorobę człowieka jako instrumentarium epistemologicznego. Katastrofa jako wydarzenie traumatyczne jest atakiem na tożsamość, w przypadku Czarnobyla stanowi również opresję wobec ciała, które staje się obce i wstrętne. Nieodwracalne zmiany zachodzące w ciele uniemożliwiają zapomnienie o wydarzeniu traumatycznym: "Jakaś całkiem nieznana rzecz burzyła cały mój dotychczasowy świat. Wpełza, włazi w człowieka... Mimo jego woli..." (Cm, s. 134-135). Czarnobyl zaczyna definiować jednostkę, podporządkowuje sobie zarówno świadomość, jak i ciało, nie tylko życie, lecz także proces umierania:

Nie wiem tylko, jak będę umierał... Kiedy umierał mój przyjaciel, spuchł, rozrósł się... Jak beczka... A sąsiad... Operator dźwigu, też tam był... Zrobił się czarny jak węgiel, zmalał do rozmiarów dziecka. [...] Gdybym mógł prosić o śmierć, to o zwyczajną, nie czarnobylską.

Cm, s. 93

Hipochondria, przekonanie o własnej ułomności prowadzi do samowykluczenia ",czarnobylan”, a fantazje na temat choroby popromiennej - ich odrzucenia społecznego:

Od pierwszych dni poczuliśmy, że jesteśmy [...] odtrąconymi. Że się nas boją. [...] Kiedy przenieśliśmy się już do Mohylewa i syn poszedł do szkoły, pierwszego dnia od razu przybiegł do domu z płaczem... Bo posadzili go razem z dziewczynką, a ta nie chciała siedzieć z napromieniowanym, bo boi się umrzeć.

Cm, s. 186

Dochodzi więc do stygmatyzacji - nadawania negatywnych cech ofiarom katastrofy czarnobylskiej, według opinii społecznej nieuleczalnie chorych, zainfekowanych nosicieli radiacji. 
Katastrofa czarnobylska zapoczątkowała proces odrodzenia się świata bez człowieka: ciało umiera, natura z kolei zaczyna się regenerować. Jeden z bohaterów Czarnobylskiej modlitwy..., obserwując bujnie kwitnące jabłonie, uświadamia sobie, że nie czuje ich zapachu (Cm, s. 120). Przyroda uwalnia się, staje się niedostępna i nieosiągalna dla ludzi. Aleksijewicz zwraca uwagę, że spośród wszystkich jej rozmówców w najmniejszym stopniu „ucierpiały” osoby, które żyły blisko natury i nie dążyły do zdobycia nad nią władzy - ich obraz świata prawie się nie zmienił ${ }^{33}$. Czas w strefie, gdzie mieszkają ci nieliczni odmieńcy, ulega zatrzymaniu. Po Czarnobylu, wraz z końcem oświeceniowych ideałów i końcem historii, natura wyswobadza się spod hegemonii człowieka.

Kształtowanie myślenia o katastrofie, reprezentacja tej tragedii i zapisanie jej $\mathrm{w}$ pamięci prowadzą do pytań o strategie wyboru utrwalanych lub marginalizowanych szczegółów, o rolę wyobraźni $\mathrm{w}$ tym procesie oraz o potrzebę zastosowania kodu etycznego. Ironizowanie, ośmieszenie ${ }^{34}$ skutków eksplozji jądrowej pomaga $\mathrm{w}$ radzeniu sobie $\mathrm{z}$ traumą po wypadku, ale jednocześnie mnoży fantazmaty na temat katastrofy: „Ile jest siedem razy siedem? Odpowiedź: "Eee, w Czarnobylu to każdy na palcach policzy!«" (Cm, s. 57). Uruchamianie wyobraźni, języka ciała, wartościowanie i estetyzacja katastrofy $\mathrm{z}$ jednej strony pomagają oddać istotę wydarzenia ekstremalnego, z drugiej - powodują zniekształcanie świadectw.

Powstanie różnych języków, sytuujących pierwszoosobowy podmiot między światem idyllicznym a światem końca, resztek, między dyskursem medialnym, naukowym a wyobrażeniowym, między wzniosłością a grozą, odzwierciedla możliwe sposoby odbierania posttraumatycznej rzeczywistości. Czarnobylska modlitwa... ukazuje różnorodność istniejących na jej temat narracji - zderzających się ze sobą, a jednocześnie tworzących dyskurs postkatastroficzny.

33 Zob. С. Алексиевич: Радиоактивный огонь. Почему опыт Чернобыля ставит под сомнение нашу картину мира. http://alexievich.info/wp-content/uploa ds/articlesDialog.pdf [dostęp: 10.04.2019].

${ }^{34}$ T. Hundorowa zaznacza: „Kultura humorystyczna, bachtinowska, burzycielska stała się może nie dominującą, ale bardzo wyraźną siłą subwersywną w Związku Radzieckim". Zob. Dyskusja panelowa z udziałem: prof. dr hab. Tamary Hundorowej, prof. dr hab. Ingi Iwasiów, dr. hab. prof. UJ Tomasza Majewskiego. Prowadzenie: Aleksandra Grzemska. W: Po Czarnobylu..., s. 363. 


\section{Bibliografia}

Aleksijewicz S.: Czarnobylska modlitwa. Kronika przyszłości. Tłum. J. Czech. Wołowiec 2018.

Andruchowycz J.: Czarnobyl, mafia $i$ ja. Tłum. L. Stefanowska. W: J. Andruchowycz: Ostatnie terytorium. Wołowiec 2002, s. 52-59.

Artwińska A.: „Odrodzity się traumy z czasów Zagłady”. Marzec 1968 jako narracja postkatastroficzna. „Poznańskie Studia Polonistyczne. Seria Literacka” 2015, nr 25, s. 187-208.

Artwińska A., Czapliński P., Molisak A., Tippner A.: Po Zagładzie. Narracje postkatastroficzne w literaturze polskiej. „Poznańskie Studia Polonistyczne. Seria Literacka" 2015, nr 25, s. 9-18.

Beck U.: Społeczeństwo ryzyka. W drodze do innej nowoczesności. Tłum. S. CieśLA. Warszawa 2006.

Berleant A.: Prze-myśleć estetykę. Niepokorne eseje o estetyce i sztuce. Tłum. M. Korusiewicz, T. Markiewka. Kraków 2007.

BoRuszKowsKa I.: Mapowanie apokalipsy - pustka i ślad czarnobylskiej zony w narracjach postczarnobylskich. W: Po Czarnobylu. Miejsce katastrofy w dyskursie wspótczesnej humanistyki. Red. I. Boruszkowska, K. Glinianowicz, A. GrzemsKa, P. KRupa. Kraków 2017, s. 80-89.

Brown K.: Czarnobyl. Instrukcje przetrwania. Tłum. T.S. Ga£ĄzKa. Wołowiec 2019.

Brown K.: Plutopia. Tłum. T. Bieroń. Wołowiec 2019.

Caruth C.: Doświadczenie niczyje: trauma i możliwość historii. Freud, Mojżesz i monoteizm. Tłum. K. BojarsKa. „Teksty Drugie” 2010, nr 6, s. 111-123.

Caruth C.: Introductio. In: Trauma. Explorations in memory. Ed. C. Caruth. Baltimore 1995, s. 3-12.

Caruth C.: Traumatyczne przebudzenia (Freud, Lacan i etyka pamięci). Tłum. K. Bojarska. W: Antologia studiów nad trauma. Red. T. Łysak. Przekł. T. Bilczewski, K. Bojarska, J. Burzyński, A. Kowalcze-Pawlik, A. Rejniak-Majewska. Kraków 2015, s. 31-57.

Czapliński P.: Katastrofa wsteczna. „Poznańskie Studia Polonistyczne. Seria Literacka" 2015, nr 25, s. 37-66.

Derrida J.: Nie, apokalipso, nie teraz! (cała naprzód, siedem pocisków, siedem orędzi). W: Idem: O Apokalipsie. Tłum. I. Boruszkowszka, K. Wojtasik. Kraków 2018, s. $103-147$.

Derrida J.: Różnia. W: Idem: Marginesy filozofii. Tłum. A. Dziadek, J. Margański, P. Pieniążek. Warszawa 2002, s. 29-56.

Dyskusja panelowa z udziałem: prof. dr hab. Tamary Hundorowej, prof. dr hab. Ingi Iwasiów, dr. hab. prof. UJ Tomasza Majewskiego. Prowadzenie: Aleksandra Grzemska. W: Po Czarnobylu. Miejsce katastrofy w dyskursie współczesnej humanistyki. Red. I. Boruszkowska, K. Glinianowicz, A. Grzemska, P. Krupa. Kraków 2017, s. 359-377.

Foucault M.: Historia seksualności. Przeł. B. Banasiak, T. Komendant, K. MatuSZEWSKI. Warszawa 1995. 
Hirsch M.: Family Frames. Photography, Narrative, and Postmemory. Cambridge 1997.

Hundorowa T.: Czarnobyl, nuklearna apokalipsa i postmodernizm. Tłum. I. BoruszкоwsKA. „Teksty Drugie” 2014, nr 6, s. 249-263.

Hundorowa T.: Gatunek Czarnobylski: wyparcie realnego i nuklearna sublimacja. Tłum. P. Tomanek. W: Po Czarnobylu. Miejsce katastrofy w dyskursie wspótczesnej humanistyki. Red. I. Boruszkowska, K. Glinianowicz, A. Grzemska, P. KRUPA. Kraków 2017, s. 55-66.

LaCAPra D.: Historia w okresie przejściowym: doświadczenie, tożsamość, teoria krytyczna. Tłum. K. Bojarska. Kraków 2009.

LaCapra D.: Trauma, nieobecność, utrata. W: Antologia studiów nad trauma. Red. T. Łysak. Przekł. T. Bilczewski, K. Bojarska, J. Burzyński, A. Kowalcze-Pawlik, A. Rejniak-Majewska. Kraków 2015, s. 59-107.

Lyotard J.-F.: Odpowiedź na pytanie: co to jest postmodernizm? Tłum. M.P. Marкоwsк. W: Postmodernizm. Antologia przekładów. Wybrał, oprac. i przedmową opatrzył R. Nycz. Kraków 1998, s. 47-61.

Sontag S.: Katastrofa w wyobrażeniu. Tłum. A. Skucińska. W: S. Sontag: Przeciz interpretacji i inne eseje. Kraków 2018, s. 279-301.

Ubertowska A.: Holokaust. Auto(tanato)grafie. Warszawa 2014.

Zавużкo O.: Planeta Piołun - Dowżenko - Tarkowski - von Trier albo dyskurs nowej grozy. Tłum. K. КотүŃsкa. W: Po Czarnobylu. Miejsce katastrofy w dyskursie współczesnej humanistyki. Red. I. Boruszkowska, K. Glinianowicz, A. GrzemSKA, P. KRupa. Kraków 2017, s. 36-51.

Žıžeк S.: Patrzac z ukosa. Wprowadzenie do Jacques'a Lacana przez kulturę popularna. Tłum. J. Margański. Warszawa 2005.

Алексиевич С.: Радиоактивный огонь. Почему опыт Чернобыля ставит под сомнение нашу картину мира. http://alexievich.info/wp-content/uploads/ articlesDialog.pdf [dostęp: 10.04.2019].

Anna Karonta - ukończyła filologię polską i słowacką na Białoruskim Uniwersytecie Państwowym, następnie w ramach Programu stypendialnego Międzynarodowego Funduszu Wyszehradzkiego - komparatystykę na Uniwersytecie Jagiellońskim. Obecnie jest doktorantką w Katedrze Teorii Literatury na Wydziale Polonistyki Uniwersytetu Jagiellońskiego. Jej zainteresowania badawcze obejmują literatury słowiańskie drugiej połowy XX i początku XXI wieku, studia nad traumą i pamięcią oraz krytykę feministyczną.

e-mail: annakaronta@gmail.com 
